\title{
СУЧАСНИЙ КОНСТИТУЦІОНАЛІЗМ: ПИТАННЯ ТЕОРІЇ ТА ПРАКТИКИ
}

Постановка проблеми. Утвердження прав і основоположних свобод людини та їх захист, $\epsilon$ важливим напрямом розвитку вітчизняної конституційної держави, а звідси й громадянського суспільства як такого. Цей процес супроводжується нинішньою потребою переосмислення правової природи конституції саме через призму доктрини конституціоналізму, іiї соціального призначення у контексті розвитку демократичних інститутів держави, зокрема їх нормативно-правової основи. Відсутність поглибленої та всебічної теоретичної розробки цієї проблеми у конституційному праві свідчить про наукову та практичну значущість, актуальність і перспективність даної тематики для практики національного державотворення.

Аналіз останніх досліджень та публікацій. Вагомий внесок питанням конституціоналізму в Україні на сучасному етапі внесли у своїх наукових працях такі вчені, як: М. О. Баймуратов, Ю. Г. Барабаш, О. В. Батанов, Ю. М. Бисага, А. М. Колодій, А. Р. Крусян, В. В. Лемак, О. О. Майданник, О. В. Марцеляк, М. В. Оніщук, В. Ф. Погорілко, М. В. Савчин, О. В. Скрипнюк, В. Я. Тацій, Ю. М. Тодика, В. Л. Федоренко, В. М. Шаповал, Ю. С. Шемшученко, О. Ф. Фрицький, О. І. Ющик та ряд інших, напрацювання котрих містить корисний за обсягом фактичний матеріал та спонукає до подальших правових досліджень зазначеної проблематики.

Мета статті. Метою даної статті $€$ висвітлення у правовому аспекті особливостей сучасного конституціоналізму в контексті теорії та практики реалізації, що сприятиме його розвитку в Україні.

Основні результати дослідження. Нині, як констатують дослідники, український конституціоналізм є у глибокій кризі, про що свідчить низка важливих ознак. Зокрема триває гостра дискусія із фундаментальних питань конституційного творення: по-перше, яка конституція сьогодні потрібна країні: говоримо про черговий етап конституційної модернізації, чи має бути повністю перезавантажена конституційна основа держави? По-друге, як прийматимемо конституцію - парламентом чи на всенародному референдумі? По-третє, якою має бути на сучасному етапі модель політичного режиму, які гарантії уникнення узурпації влади? Для України - це своєрідний виклик, що потребує продовження конституційних дебатів саме у напрямі конструювання нового конституційного порядку [1, с. 3].

Із цього приводу А. Р. Крусян зазначає, що актуалізація теорії і практики сучасного конституціоналізму спричинена процесами конституційного реформування в Україні, оскільки політико-правова система конституціоналізму є важливою інструментальною і процедурною гарантією становлення, розвитку, функціонування громадянського суспільства та правової держави, тому конституціоналізм уявляється основною метою конституційних перетворень в країні [2].

Беззаперечним є той факт, указує П. Б. Стецюк, що в сучасному вітчизняному конституційному праві науковці не дійшли до спільної думки щодо визначення дефініції та складових поняття «конституціоналізм». Зокрема, конституціоналізм як політико-правова категорія, як доктринальне вчення появляється після виникнення та утвердження конституції держави в сучасному розумінні даного терміна. Він $є$ нерозривним і прямо похідним від конституції держави. Хоч не завжди факт наявності конституції автоматично означає появу тої чи іншої моделі конституціоналізму. Однак без появи (наявності) самої конституції (у широкому розумінні цього поняття), говорити про конституціоналізм не доводиться [3, с. 60]. Як підкреслює Г. П. Циверенко, конституціоналізм розглядається як необхідний атрибут правової держави та ліберальної демократії, у якій поважаються гідність особи, гарантовані права та свободи громадян, не допускається втручання у сфе- 
ру приватних інтересів. У сучасній політико-правовій літературі використовуються різні підходи до визначення конституціоналізму, оскільки XX століття із його масштабними соціально-політичними потрясіннями, формуванням загальнолюдських цінностей, появою та зростанням ролі міжнародних стандартів прав людини та громадянина надало сучасній конституційній доктрині нової спрямованості [4, с. 171$]$.

В. М. Шаповал, досліджуючи проблему сучасного конституціоналізму, у своїй праці «Сучасний конституціоналізм» констатує можливості його різних інтерпретацій, а саме: конституціоналізм - «це передусім політико-правова ідеологія, інтелектуальні узагальнення, притаманні певному етапу історичного розвитку». «Водночас, - зазначається далі, - конституціоналізм нерідко сприймають як суспільно-політичний рух, спрямований на реалізацію відповідних ідей». Окрім цього, «конституціоналізм також розглядають як державне правління у широкому сенсі (управління державними справами), обмежене за змістом конституції. Нарешті, конституціоналізм іноді ототожнюють із практикою конституційного регулювання суспільних відносин» [5, с. 17].

В Україні конституціоналізм, підкреслює М. І. Абдулаєв, характеризується науково-практичною невизначеністю його сучасного змісту та, маючи певні історичні витоки, перебуває у стадії формування і втілення у науку й практику державотворення. Конституцією України закріплено нормативно-правову основу конституціоналізму, проте процес практичної іiі реалізації свідчить про необхідність здійснення конституційної та політичної реформ [6, с. 114].

На сучасному етапі формування конституціоналізму в Україні вчені визначають наступні проблеми: по-перше, сучасна державотворча і правотворча практика України дедалі більш переконливо засвідчує проблему «розриву» між об'єктивним рівнем розвитку суспільних відносин і тими правовими нормами, які покликані їх врегульовувати. Унаслідок цього поглиблюється диференціація між «фактичною» і «юридичною» конституцією, що своєю чергою поступово нівелює роль конституційного права (і права загалом) у житті і розвиткові суспільства. однією 3 причин такого розриву $є$ відсутність або нерозвиненість на рівні сучасної правової культури суспільства цінностей конституціоналізму. Це означає, що конституціоналізм в Україні тільки набуває ознак невід'ємного елементу правової культури і правової свідомості суспільства (наразі під поняттям «правова свідомість» маємо на увазі «оцінку права, яка існує у суспільстві, відображає критику діючого права, формує певні надії і побажання до правової сфери, iї змін, яка визначає, що вважати правомірним і неправомірним»). По-друге, подальший розвиток конституційного права України не може не враховувати й суб'єктивний елемент його реалізації, адже у багатьох випадках проблема полягає не стільки у відсутності або суперечливості тих чи інших конституційних норм, скільки у банальному небажанні їх виконувати або ж їх реалізовувати. За цієї причини конституціоналізм має стверджуватись в Україні не тільки шляхом удосконалення чинного конституційного законодавства, наповнення його новими загальновизнаними гуманістичними принципами і цінностями, розробкою нових конституційних процедур, які б дозволили посилити гарантії прав і свобод людини і громадянина в Україні тощо, але й через становлення нового типу правової культури, одним з найважливіших елементів якої є конституціоналізм, його цінності і принципи. По-третє, процес конституційного регулювання будь-яких суспільних відносин не може здійснюватись виключно на основі примусово-репресивної моделі, коли головною причиною дотримання конституції є наявність жорстких і реальних санкцій, які невідворотно застосовуються у разі її порушення. Не заперечуючи і не применшуючи ролі інститутів конституційної відповідальності, варто звернути увагу й те, що у розвинених демократичних державах часто головним стимулом дотримання конституції $\epsilon$ повага до неї, а також незаперечне визнання конституціоналізму як базисної цінності та правової культури і правової свідомості [7].

Конституціоналізм як конституційно-правова цінність, наголошує А. Р. Крусян, покликаний запобігати концентрації влади в одних руках, тобто узурпації влади. Систему сучасного українського конституціоналізму спрямовано на обмеження публічної влади на користь громадянського суспільства; прав та інтересів людини і громадянина; для визнання, забезпечення та захисту конституційно-правової свободи людини. У зв'язку з цим актуалізуються проблеми ефективності механізму «стримувань і противаг» в системі поділу державної влади, а також організації публічної влади на місцях, зокрема через удосконалення місцевого самоврядування як фактора, що стримує виконавчу владу на рівні місцевого управління та як дієвого інституту громадянського суспільства, формування якого $є$ необхідною соціальною передумовою конституціоналізму [8]. 
Український конституціоналізм за своїм характером є перехідним, оскільки йде важкий процес подолання пострадянської практики правління і він номінально займає проміжне положення між ліберально-демократичним та соціальним конституціоналізмом, хоча практика правління набуває мало спільного із певними сучасними моделями конституціоналізму. Такий розрив між номінальним конституціоналізмом та практикою правління відображає кризу конституційних цінностей в Україні [9, с. 141].

Відтак світовий та вітчизняний досвід конституціоналізму свідчить, що не існує загальноприйнятої схеми прийняття або ревізії конституції (у формі певного правового ідеалу). Виділяють принаймні чотири моделі прийняття або ревізії конституції: 1) прийняття конституції внаслідок iii розробки спеціальною конституційною комісією із наступним затвердженням на референдумі; 2) прийняття конституції установчими зборами, яке може бути ускладнене у результаті протистояння гілок влади та провідних політичних інститутів суспільства; 3) прийняття конституції парламентом при широкому залученні народу до розробки та обговорення проекту основного закону держави, що передбачає існування стійких демократичних інституцій та тривалих парламентських традицій; 4) поетапне реформування конституції, яке передбачає політичний компроміс і прийняття з урахуванням юриспруденції Конституційного Суду на проміжному етапі рамкового документа, який би володів характером так званої «малої конституції» [10].

Загалом, зазначає М. В. Савчин, такі механізми прийняття чи внесення змін до конституції у світовій практиці поєднуються певним чином, що відображає національні традиції та певні конкретно-історичні обставини [11, с. 227-228].

Висновки. Як бачимо, розвиток конституціоналізму в Україні на сучасному етапі, зважаючи на всю його складність, часто суперечливість, що включає тим самим багатоаспектність даного явища, зумовлює становлення державності саме на конституційних засадах, яка є запорукою демократичного, правового та соціального змісту розбудови країни в контексті з утвердженням громадянського суспільства, де конституційно-правова свобода людини з її інтересами виступає метою сучасного українського конституціоналізму, а звідси його й основою. Таким чином, людина у доктрині та практиці конституціоналізму посідає провідне місце, оскільки вона є енергетичним центром парадигми самого конституціоналізму, головний ціннісний орієнтир його подальшого розвитку, індикатор перевірки на можливість реалізації конституційної теорії, ідеології та практики у державотворчий процес.

Отже, конституціоналізм в Україні, що невід'ємно пов'язаний із процесом державотворення, $\epsilon$ його основоположною складовою. Для розвитку конституціоналізму важливим $є$ не лише сам факт наявності Основного Закону держави, а й передусім втілення його положень у практику державотворення, реальний вплив конституції на становлення правової системи на демократичних засадах. Тому основними завданнями України на сучасному етапі $є$ проведення комплексу реформ та забезпечення фактичної реальності конституціоналізму, за якого права людини виступають найвищою соціальною цінністю. Сучасний конституціоналізм грунтується на нормативно-правовій основі, тобто повному його закріпленні в законодавстві. Формування сучасного українського конституціоналізму зумовлене ефективністю правового регулювання суспільних відносин, основою якого $\epsilon$ система законодавства при визнанні пріоритету саме Конституції як Основного Закону держави.

\section{Список використаних джерел}

1. Середа В. В. Концептуальні засади сучасного конституціоналізму в Україні // Сучасний конституціоналізм: проблеми теорії та практики (до 20-ї річниці Конституції України): матеріали наукового семінару (24 червня 2016 р.) / упор. М. В. Ковалів. - Львів : ЛьвДУВС, 2016. - 372 с.

2. Крусян А. Р. Сучасний конституціоналізм - мета конституційних перетворень в Україні / А. Р. Крусян // Вісник Харк. нац. ун-ту. - Серія Право. - 2009. - № 841. - С. $42-47$.

3. Стецюк П. Б. Основи теорії конституції та конституціоналізму. Частина перша : посіб. для студентів / П. Б. Стецюк. - Львів : Астролябія, 2003. - 232 с.

4. Циверенко Г. П. Основні підходи до визначення поняття «конституціоналізм» у сучасній науковій думці / Г. П. Циверенко // Держава та регіони. - Серія Право. - 2009. - № 1. - С. 171-175.

5. Шаповал В. М. Сучасний конституціоналізм / В. М. Шаповал. - К. : Юрид. Фірма «Салком»; Юрінком Інтер, 2005. $-560 \mathrm{c}$.

6. Абдулаев М. И. Права человека и закон: Историко-теоретические аспекты / М. И. Абдулаев. - М. : СПб. : Юрид. центр Пресс, 2004. - 322 с. 
7. Загальна теорія держави і права : підруч. для студ. юрид. вищих навч. закл. / за ред. М. В. Цвіка, О. В. Петришина. - Х., 2009. - 550 с.

8. Крусян А. Р. Сучасний український конституціоналізм : [моногр.] / А. Р. Крусян. - К. : Юрінком Інтер, 2010. $560 \mathrm{c.}$

9. Савчин М. В. Конституціоналізм і природа конституції : моногр. - Ужгород : Поліграфцентр «Ліра», 2009. - $372 \mathrm{c}$.

10. Бруннер Георг. Конституційнодавчий процес у Німеччині та Східній Європі / Георг Бруннер. - Кельн: б. н., 1994. $-34 \mathrm{c}$.

11. Савчин М. В. Конституційний лад і конституція: проблема співвідношення установчої та інституційної влади / М. В. Савчин // Держава і право: зб. наук. праць. Юридичні і політичні науки. Вип. 28. - К. : ІДП НАН, 2005. - C. 224-229.

\section{References}

1. Sereda $V$. V. Kontseptualni zasady suchasnoho konstytutsionalizmu v Ukraini // Suchasnyi konstytutsionalizm: problemy teorii ta praktyky (do 20-yi richnytsi Konstytutsii Ukrainy): materialy naukovoho seminaru (24 chervnia 2016 r.) / upor. M. V. Kovaliv. - Lviv : LvDUVS, 2016. - 372 s.

2. Krusian A. R. Suchasnyi konstytutsionalizm - meta konstytutsiinykh peretvoren v Ukraini / A. R. Krusian // Visnyk Khark. nats. un-tu. - Seriia Pravo. - 2009. - № 841. - S. $42-47$.

3. Stetsiuk P. B. Osnovy teorii konstytutsii ta konstytutsionalizmu. Chastyna persha : posibnyk dlia studentiv / P. B. Stetsiuk. - Lviv : Astroliabiia, 2003. - 232 s.

4. Tsyverenko H. P. Osnovni pidkhody do vyznachennia poniattia «konstytutsionalizm» u suchasnii naukovii dumtsi / H. P. Tsyverenko // Derzhava ta rehiony. - Seriia Pravo. - 2009. - № 1. - S. 171-175.

5. Shapoval V. M. Suchasnyi konstytutsionalizm / V. M. Shapoval. - K. : Yuryd. Firma «Salkom»; Yurinkom Inter, 2005. $-560 \mathrm{~s}$.

6. Abdulaev M. Y. Prava cheloveka y zakon: Ystoryko-teoretycheskye aspektы / M.Y. Abdulaev. - M. : SPb.: Yuryd. tsentr Press, 2004. - 322 s.

7. Zahalna teoriia derzhavy i prava: pidruchnyk dlia stud. yuryd. vyshchykh navch. zakl. / za red. M. V. Tsvika, O. V. Petryshyna. - Kh., 2009. - $550 \mathrm{~s}$.

8. Krusian A. R. Suchasnyi ukrainskyi konstytutsionalizm: [monohr.] / A. R. Krusian. - K. : Yurinkom Inter, 2010. -560 s.

9. Savchyn M. V. Konstytutsionalizm i pryroda konstytutsii : Monohr. - Uzhhorod : Polihraftsentr «Lira», 2009. - $372 \mathrm{~s}$.

10. Brunner Heorh. Konstytutsiinodavchyi protses u Nimechchyni ta Skhidnii Yevropi / Heorh Brunner. - Keln: b.n., 1994. $-34 \mathrm{~s}$.

11. Savchyn M. V. Konstytutsiinyi lad i konstytutsiia: problema spivvidnoshennia ustanovchoi ta instytutsiinoi vlady / M. V. Savchyn // Derzhava i pravo: Zb. nauk. prats. Yurydychni i politychni nauky. Vyp. 28. - K. : IDP NAN, 2005. S. 224-229.

\section{Магновський І. Й. Сучасний конституціоналізм: питання теорії та практики}

Стаття присвячена дослідженню конституціоналізму в контексті теорії та практики його реалізації. Наголошено на потребі переосмислення правової природи конституції саме через призму доктрини конституціоналізму. Зосереджено увагу на актуалізації теорії та практики сучасного конституціоналізму, яка спричинена процесами конституційного реформування в Україні. Відзначено політико-правову систему конституціоналізму, що $\epsilon$ важливою інструментальною і процедурною гарантією становлення, розвитку та функціонування громадянського суспільства і правової держави. Указано на науково-практичну невизначеність сучасного змісту українського конституціоналізму, у зв'язку з чим констатується можливість його різних інтерпретацій. Зазначається, що український конституціоналізм перебуває у стадії формування і втілення у науку й практику державотворення. Позначено, що систему сучасного українського конституціоналізму спрямовано на обмеження публічної влади на користь громадянського суспільства; прав та інтересів людини і громадянина; для визнання, забезпечення та захисту конституційно-правової свободи людини загалом. Стверджується, що український конституціоналізм за своїм характером є перехідним, оскільки йде важкий процес подолання пострадянської практики правління. Підкреслено, що розвиток конституціоналізму в Україні на сучасному етапі, зважаючи на всю його складність, часто суперечливість, включаючи тим самим багатоаспектність даного явища, зумовлює становлення державності саме на конституційних засадах, яка є запорукою демократичного, правового та соціального змісту розбудови країни в контексті з утвердженням громадянського суспільства, де конституційно-правова свобода людини з їі інтересами виступає метою сучасного українського конституціоналізму, а звідси його й основою. Констатовано, що конституціоналізм в Україні, який невід'ємно пов'язаний із процесом державотворення, є його основоположною складовою. Звернено увагу, що для розвитку конституціоналізму важливим є не лише сам факт наявності Основного Закону держави, а й передусім втілення його положень у практику державотворення, реальний вплив конститу- 
ції на становлення правової системи на демократичних засадах, де основними завданнями Української держави на сучасному етапі є проведення комплексу реформ та забезпечення фактичної реальності конституціоналізму, за якого права людини виступають найвищою соціальною цінністю. Акцентовано, що сучасний конституціоналізм грунтується на нормативно-правовій основі, тобто повному його закріпленні в законодавстві, формування якого зумовлене ефективністю правового регулювання суспільних відносин, основою котрого є система законодавства при визнанні пріоритету саме Конституції як Основного Закону держави.

Ключові слова: правова природа, конституціоналізм, конституція, парадигма, конституційно-правова свобода людини.

\section{Mahnovskyi I. Y. Modern constitutionalism: questions of theory and practice}

The article is devoted to research Constitutionalism in the context of theory and practice of its realization. It is emphasized on the need to rethink the legal nature of the constitution precisely because of the prism of the doctrine of constitutionalism. The focus is on actualization of the theory and practice of modern constitutionalism, which is caused by the processes of constitutional reform in Ukraine. The political and legal system of constitutionalism, which is an important instrumental and procedural guarantee of the formation, development and functioning of civil society and the rule of law, is noted. It is indicated on the scientific and practical uncertainty of the contemporary content of Ukrainian constitutionalism, in connection with which it is stated the possibility of its various interpretations. It is noted that Ukrainian constitutionalism is in the stage of formation and implementation in the science and practice of state-building. It is noted that the system of modern Ukrainian constitutionalism is aimed at limiting public authority in favor of civil society; rights and interests of a person and a citizen; to recognize, ensure and protect the constitutional and legal freedom of man in general. It is alleged that Ukrainian constitutionalism is inherently transitive because of the difficult process of overcoming the post-Soviet practice of government. It is emphasized that the development of constitutionalism in Ukraine at the present stage, due to its complexity, often contradictory, including the multidimensional nature of this phenomenon, causes the formation of statehood on a constitutional basis, which is the key to the democratic, legal and social maintenance of the country's development in the context of approval civil society, where the constitutional and legal freedom of man with his interests serves the purpose of modern Ukrainian constitutionalism, and hence it is the basis. It is stated that constitutionalism in Ukraine, which is inextricably linked with the process of state-building, is its fundamental component. Attention is drawn to the fact that for the development of constitutionalism it is important not only the very existence of the Basic Law of the state but also the implementation of its provisions in the practice of state formation, the actual impact of the constitution on the establishment of the legal system on a democratic basis, where the main tasks of the Ukrainian state at the present stage is the holding of a complex reforms and ensuring the actual reality of constitutionalism, in which human rights are of the highest social value. It is emphasized that modern constitutionalism is based on the normative-legal basis, that is, its full consolidation in the legislation, the formation of which is determined by the effectiveness of the legal regulation of social relations, the basis of which is the system of legislation in recognizing the priority of the Constitution itself as the Basic Law of the State.

Key words: legal nature, constitutionalism, constitution paradigm, constitutional and legal freedom of man.

DOI: 10.33.66.3/2524-017X-2019-10-61-65 